\title{
Hurricane wind shelter retrofit room standards for existing houses
}

\author{
N. Yazdani ${ }^{1}$, T. Townsend ${ }^{1} \&$ D. KilCollins ${ }^{2}$ \\ ${ }^{I}$ Florida A \& M University- Florida State College of Engineering, USA \\ ${ }^{2}$ Florida Department of Community Affairs, USA
}

\begin{abstract}
The objective of this study was to develop a design and construction technique for an in-home Retrofit Room hurricane shelter, which is an alternative to the FEMA tornado Safe Room. Such a room will be able to withstand hurricane wind speeds up to $225 \mathrm{~km} / \mathrm{h}(140 \mathrm{mph})$ and windborne debris. This study developed design and construction techniques for a more economic Retrofit Room. The retrofitting is achieved through reinforcing existing walls and roofs of typical small interior rooms with plywood sheets, steel plate anchor bolts and hurricane straps. The in-house shelter will offer significant occupant protection and reduce the demand on public shelters in the event of a Category 4 hurricane or an F2 level tornado. The average material and labor cost of a hurricane Retrofit Room is about $\$ 3,100$, almost half of the typical cost for a FEMA Safe Room.

Keywords: Retrofit Room, in-home shelter, hurricane winds, windborne debris, evacuation.
\end{abstract}

\section{Introduction}

The state of Florida and other storm-prone states have experienced a considerable impact from storm damage due to the hazardous effects of high winds and flooding from severe tropical storms and hurricanes. In recent years, residents have suffered tremendous property damage and even loss of life due to extreme storm hazards. Most residential houses are constructed in accordance with local or national building codes that may not take into account the effects of extreme winds and windborne debris associated with hurricanes. Hurricanes such as Andrew and Opal have illustrated the susceptibility of Florida structures to these damaging storm effects. The growing concern for the state's vulnerability 
to storm-induced damage has made hurricane awareness and preparedness top priority for emergency management organizations. The Federal Emergency Management Agency (FEMA [1]) has developed design and construction techniques to encourage homeowners to install in-home "Safe Rooms" that provide protection from tornado strength winds.

The objective of this study was to develop and test a Retrofit Room, which is an in-residence shelter alternative to the FEMA Safe Room, geared towards existing homes. Such a room will be able to withstand Category 4 hurricane and F2 level tornadic wind speeds up to $225 \mathrm{~km} / \mathrm{h}$ (140 mph), a typical design wind speed for south Florida from the recently implemented Florida Building Code (FBC [2]). The Retrofit Room design incorporates methods of externally or internally reinforcing existing walls and roof sections of typical interior rooms such as bathrooms, closets or utility rooms. The in-home shelter offers significant occupant protection and reduces the demand on public shelters during the events of extreme hurricanes and major tornadoes. The developed design and construction specifications for the Retrofit Room were based on known performance and strengths of existing materials and technology. Because the study reported herein was concerned with average Florida residential homes, it was limited to the performance standard development of Retrofit Rooms for single-story above ground structures. More specifically, the work targets Retrofit Room techniques for wood-frame and concrete masonry structures with slab-ongrade foundations only.

\section{Background}

The FEMA Safe Room is primarily geared towards newly constructed houses. As such, accommodations can be conveniently made during construction to provide adequate walls, foundations and other components to create the shelter. However, it is quite difficult to modify an existing house to conform to the specifications of the FEMA Safe Room. In order to add a Safe Room with concrete or concrete masonry walls to an existing residential house, the existing slab foundation has to be partially removed and replaced it with a thickened slab. In the case of a wood-framed Safe Room, removal of the foundation is not necessary. However, resistance to wind-borne missiles may not be sufficient enough to comply with the FEMA Safe Room design specifications. As a result, the cost of adding a FEMA Safe Room to an existing home is about 20 percent more than that needed for a new home. A tornadic design wind velocity of 400 $\mathrm{km} / \mathrm{h}(250 \mathrm{mph})$ is the basis for the FEMA Safe Room design. This approach provides a "gold standard" of in home shelter safety for the occupants. However, this approach also results in a relatively expensive Safe Room design. On average, the cost to build a Safe Room in a new home ranges from $\$ 2,000$ $\$ 6,000$ (FEMA [1]). It is apparent that, though appropriate and feasible for new construction, the FEMA Safe Room may not be practical or cost-efficient for existing houses. Thus, the need for a viable and alternate affordable design for an in-home shelter for existing houses is evident. The basis for the developed Retrofit Room design is a typical hurricane wind speed of $225 \mathrm{~km} / \mathrm{h}(140 \mathrm{mph})$. 
The resulting Retrofit Room is expected to be cheaper than the typical FEMA Safe Room, with reasonable "silver standard" of in-home sheltering for hurricane protection.

\section{Retrofit Room}

The success of the developed Retrofit Room technique is based solely on its performance in withstanding the effects associated with extreme wind events. As a standard measure, the shelter design was evaluated on its ability to resist the pressures imposed by extreme hurricane strength winds, to maintain the Room envelope without failure or separation and to resist the impacts of windborne debris. Single-family residential houses with wood framed or concrete block masonry structures on slab-on-grade foundations were chosen herein for the Retrofit Room implementation. Numerous house plans from local and state government permitting authorities were obtained. Three typical existing houses located across the state of Florida were chosen as model plans for analysis. A standard $1.8 \mathrm{~m} \times 1.8 \mathrm{~m} \times 2.4 \mathrm{~m}(6 \mathrm{ft} \times 6 \mathrm{ft} \times 8 \mathrm{ft})$ windowless interior room was chosen for analysis based on selected Florida sample houses. The maximum wall

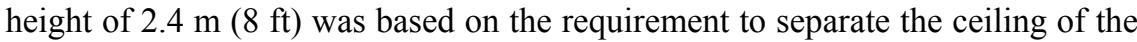
Retrofit Room from the original house ceiling.

\section{Retrofit techniques and materials}

The retrofit techniques considered were based on the proven strategies for the FEMA Safe Room construction. Strengthening structural components with external sheathing, extra members, additional anchorage and better connections were some of the retrofit strategies considered. In addition, replacing existing doors with stronger ones and applying hurricane straps to roof trusses were also considered to further increase the performance of the Retrofit Room. The materials used in the design were chosen based on their known strengths and ability to perform under extreme wind conditions. Moreover, the materials most capable of resisting the effects of debris impact, overturning and uplift were utilized. The selected items included plywood, wood stud members, steel sheathing, debris impact resistant doors, hurricane straps, anchor bolts and nails. To ensure practicality and accessibility for homeowners, materials readily available at local hardware stores were chosen.

Small interior rooms tend to remain intact after a storm even when the rest of the house is severely damaged or destroyed (TTU [3]). Therefore, windowless small interior rooms such as bathrooms, closets or utility rooms were selected for analysis. The following performance standards were examined: (a) Required wind resistance; (b) No overturning, sliding or uplift failure; (c) No separation of walls, ceiling and floor, and (d) No component failure from debris impact.

\subsection{Retrofit choices}

A total of five typical wall sections were developed and analyzed herein. Four of the designs were developed for typical timber stud wall sections and one for 
typical concrete masonry wall sections. The first trial design combined two layers of $12 \mathrm{~mm}\left(1 / 2^{\prime \prime}\right)$ plywood with one layer of 14 gauge steel sheathing. The

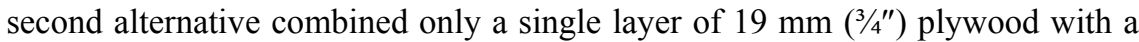
layer of 14 gauge steel sheathing. The third choice involved only one layer of 14 gauge steel sheathing, while the fourth used two layers of $19 \mathrm{~mm}\left(3 / 4^{\prime \prime}\right)$ plywood. The fifth Retrofit Room design accommodated CMU wall sections, consisting of $200 \mathrm{~mm} \times 200 \mathrm{~mm} \times 400 \mathrm{~mm}$ (8 in x 8 in x 16 in). A sample of the wall section can be seen in figure 1. CMU blocks with fully grouted cells reinforced with vertical bars at a minimum spacing of $0.6 \mathrm{~m}$ (24 in) on center. Each of the wall alternatives also included a $12 \mathrm{~mm}\left(1 / 2^{\prime \prime}\right)$ layer of gypsum wallboard as the interior wall finish. Figure 2 shows the typical interior Retrofit Room plan view.

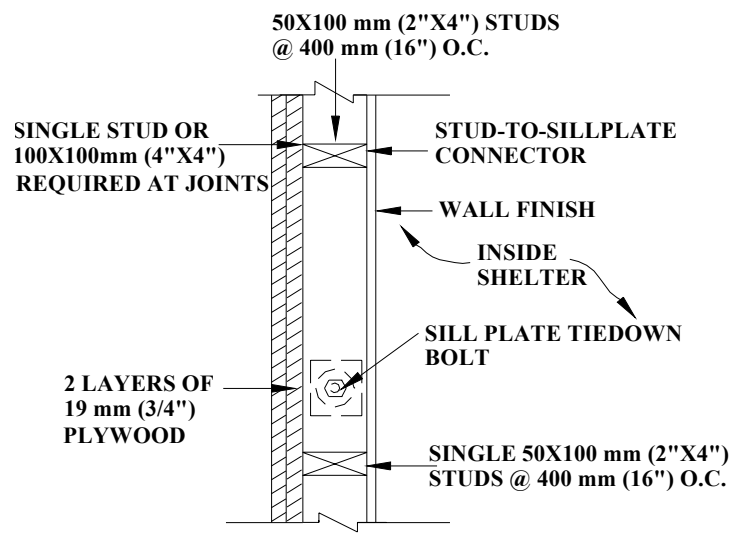

Figure 1: $\quad$ Alternative 4 wall section detail.

\subsection{Wind pressure}

To properly account for lateral and uplift loads, the wind load design of the Retrofit Room was based on the approach specified in ASCE 7-98 Minimum Design Loads for Buildings and Structures (ASCE [4]). For this study an overall basic speed of $225 \mathrm{~km} / \mathrm{h}$ (140 mph) was used, which encompasses the majority of the regions throughout the state of Florida. The following parameters were used to calculate the wind pressures: (1) importance factor $I=1.0$, which adjusts wind speed to annual probabilities for other than 50 year recurrence; (2) A site exposure $\mathrm{C}$ for buildings in open terrain with scattered obstructions having heights generally less than $9.1 \mathrm{~m}$ (30 ft); (3) A conservative directionality factor, $\mathrm{K}_{\mathrm{d}}$, of 1.0 was used because wind directions may change considerably during extreme wind events; (4) An internal pressure coefficient of $+/-0.18$, signifying pressures acting toward and away from the internal surfaces for enclosed residential shelters. The velocity pressure, $\mathrm{q}_{\mathrm{z}}$, calculated for the standard $1.8 \mathrm{~m} \mathrm{x}$ $1.8 \mathrm{~m} \times 2.4 \mathrm{~m}(6 \mathrm{ft} \times 6 \mathrm{ft} \times 8 \mathrm{ft}$ ) room for both the Main Wind Force Resisting 
System (MWFRS) and Components and Cladding (C\&C) was $2.04 \mathrm{kN} / \mathrm{m}^{2}$ (42.65 psf). The calculated MWFRS wind pressures acting on the windward and leeward walls were $1.48 \pm 0.37 \mathrm{kN} / \mathrm{m}^{2}(30.95 \pm 7.68 \mathrm{psf})$ and $-0.92 \pm 0.37 \mathrm{kN} / \mathrm{m}^{2}$ $(-19.34 \pm 7.68 \mathrm{psf})$, respectively.

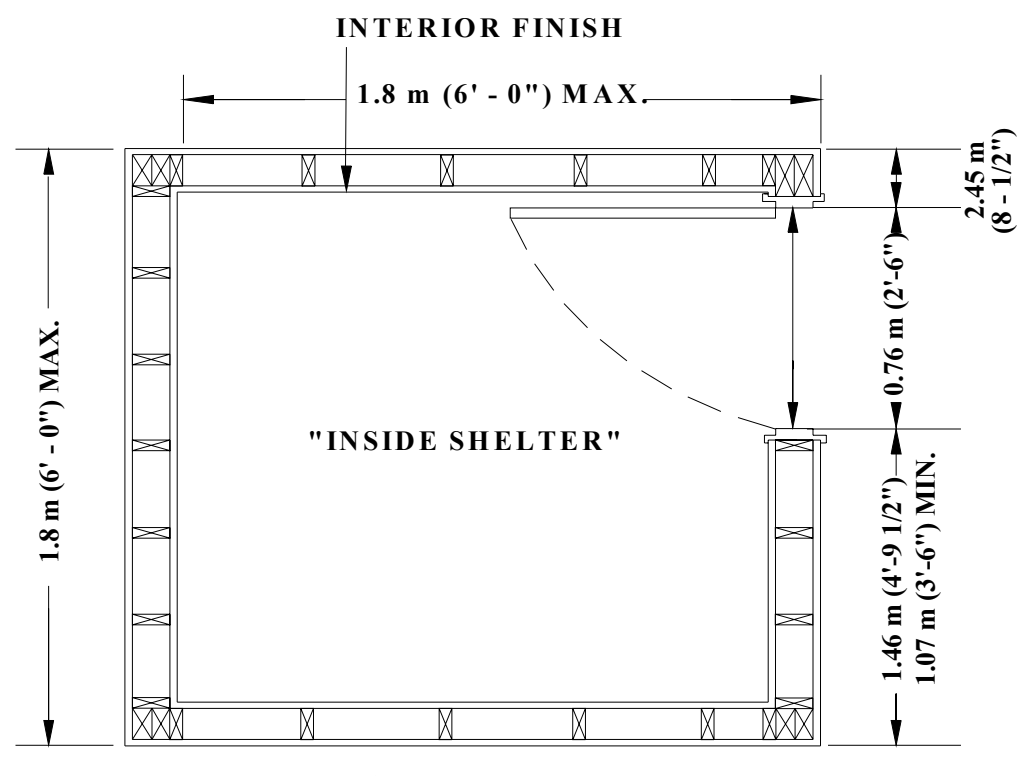

TYPICAL PLAN VIEW

Figure 2: $\quad$ Typical retrofit room plan view.

The roof wind pressures were $-2.41 \pm 0.37 \mathrm{kN} / \mathrm{m}^{2}(-50.29 \pm 7.68 \mathrm{psf})$ at a horizontal distance of half the wall height from the windward edge, and $-1.3 \pm$ $0.37 \mathrm{kN} / \mathrm{m}^{2}(-27.08 \pm 7.68 \mathrm{psf})$ thereafter. The $\mathrm{C} \& \mathrm{C}$ wind pressure values were $2.51 \mathrm{kN} / \mathrm{m}^{2}(-52.46 \mathrm{psf})$ and $-3.00 \mathrm{kN} / \mathrm{m}^{2}(-62.70 \mathrm{psf})$ acting at the middle and corner zones of the walls, respectively. The $\mathrm{C} \& \mathrm{C}$ roof wind pressures at the interior and corner zones were $-2.41 \mathrm{kN} / \mathrm{m}^{2} \quad(-50.33 \mathrm{psf})$ and $5.88 \mathrm{kN} / \mathrm{m}^{2}$ (122.83 psf), respectively.

\section{Results and discussion}

The walls of the Retrofit Room were analyzed as exterior walls, based on the assumption that the rest of the house will fail in a storm. A supplementary wind analysis showed that the overall building envelopes for the sample houses from Table 1 would withstand the $225 \mathrm{~km} / \mathrm{h}$ (140 mph) wind velocity. However, the wall and roof sections failed to satisfy windborne debris impact resistance, as discussed later. 


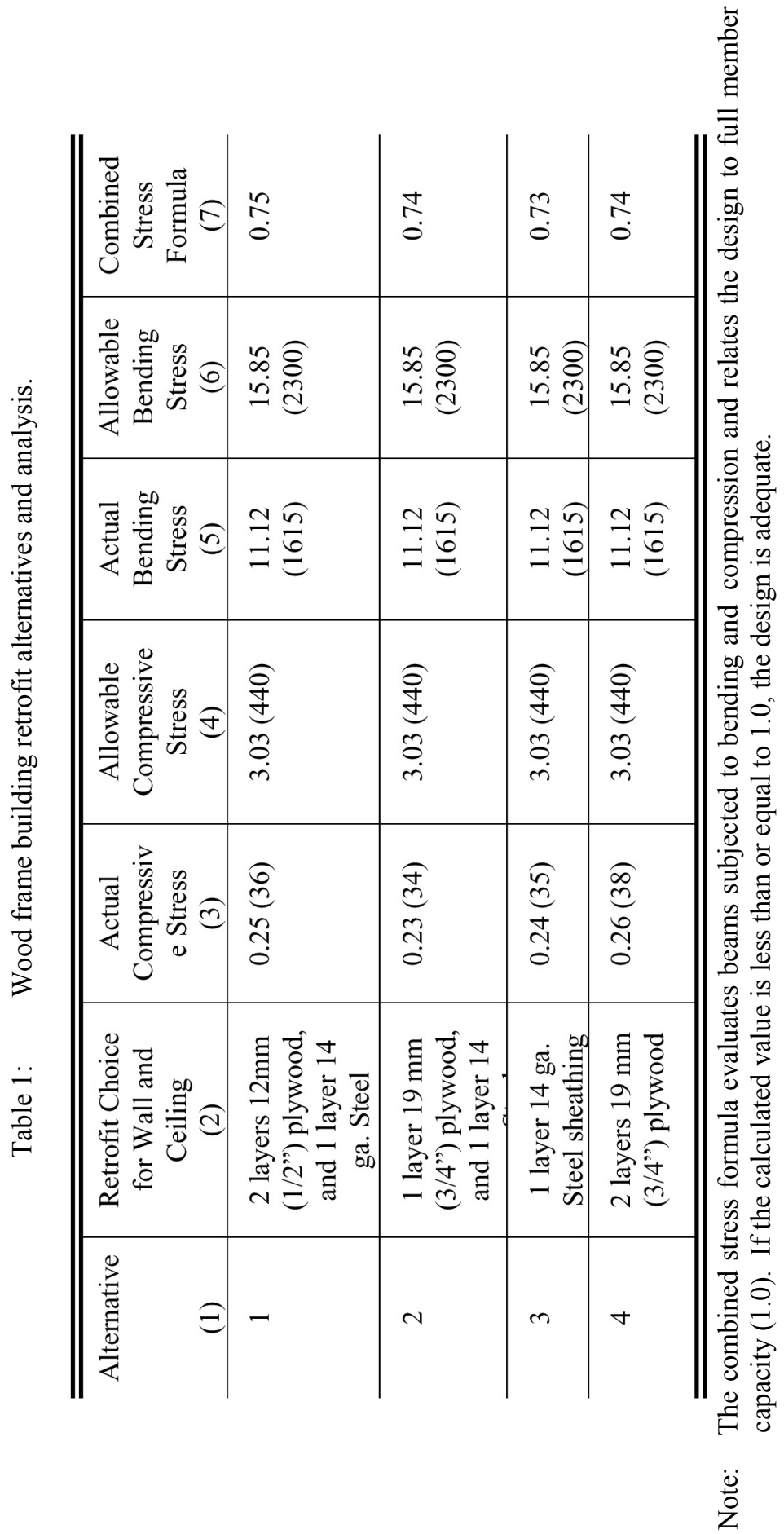


The Allowable Stress Design (ASD) and Strength Design methods were used for all calculations including load combinations and wall capacity. The analysis of the stud wall was performed for combined bending and compression (Breyer [5]). Similarly, the design of the CMU wall followed specifications for slender wall design with out-of-plane loading (Taly [6]). Table 1 lists the analysis details for the wood frame and CMU wall section alternatives. Using SPF grade No. 2 and Btr. tabulated stresses (NDS [7]), the allowable compressive and bending stresses were calculated for each retrofit alternative and found to be $3.03 \mathrm{MPa}$ $\left(440 \mathrm{lbs} / \mathrm{in}^{2}\right)$ and $15.85 \mathrm{MPa}\left(2300 \mathrm{lbs} / \mathrm{in}^{2}\right)$, respectively. Actual compressive and bending stresses for each alternative were well below allowable stresses and adequate enough to withstand design wind pressures. The calculated combined stress values were all less than 1.0 (full member capacity), signifying over design. The fully grouted CMU wall alternative produced an actual bending moment of $0.32 \mathrm{kN}-\mathrm{m}$ (239 lb-ft), which is significantly less than the allowable design moment. The vertical steel ratio provided is less than the maximum allowed steel ratio and thus adequate for the design.

$$
\left(\frac{\mathrm{f}_{\mathrm{c}}}{\mathrm{Fc}}\right)^{2}+\left(\frac{1}{1-\frac{\mathrm{f}_{\mathrm{c}}}{\mathrm{F}_{\mathrm{cE}}}}\right) \cdot \frac{\mathrm{f}_{\mathrm{b}}}{\mathrm{F}_{\mathrm{b}}} \leq 1.0
$$

where $\mathrm{f}_{\mathrm{c}}=$ actual compressive stress

$\mathrm{f}_{\mathrm{b}}=$ actual bending stress

$\mathrm{F}_{\mathrm{c}}=$ Allowable compressive stress

$\mathrm{F}_{\mathrm{b}}=$ Allowable bending stress

\subsection{Wall modifications}

In smaller houses that may not have exclusively interior rooms, it is necessary to use at most two exterior walls in the design of the Retrofit Room. The exterior walls will maintain their function as structural load bearing walls if needed. However, measures must be taken to allow the walls to detach from the Retrofit Room during the event of a hurricane. For the stud wall, this involves notching the studs just above the ceiling of the retrofit room, reducing the width and causing the upper part of the wall to break away when additional loads from wind pressures are applied. The imposed notch results in a stud area reduction from $2626 \mathrm{~mm}^{2}$ to $3387 \mathrm{~mm}^{2}$ ( $4.07 \mathrm{in}^{2}$ to $5.25 \mathrm{in}^{2}$ ), or about 22.5 percent. For the concrete masonry wall, construction joints are needed to allow for lateral movement to prevent damage to the Retrofit Room assembly and maintain structural integrity. Cutting through the masonry with a saw, and inserting a foam rod to create a functional joint can achieve post-construction installation of joints.

\subsection{Roof structure}

The Retrofit Room ceiling was analyzed as unattached to the existing house ceiling. The roof of the shelter consists of $50 \mathrm{~mm} \times 150 \mathrm{~mm}$ ( 2 in $\times 6$ in) joists 
spaced at $400 \mathrm{~mm}$ (16 in) on center and sheathing. The roof sheathing material corresponds with the sheathing used for that particular wall section. For instance,

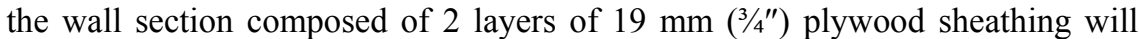
have the same sheathing materials for the roof. Blocking may be provided between joists as auxiliary members.

\subsection{Anchorages and connections}

It was determined through Alternative 4 analysis that for adequate shear capacity, the nailing pattern for the first layer of plywood sheathing required $10 \mathrm{~d}$ nails spaced at $75 \mathrm{~mm}$ ( $3 \mathrm{in})$ on center at edges and $150 \mathrm{~mm}(6 \mathrm{in})$ on center in field. For the second layer, 16d nails were used with the same spacing requirements. The steel sheathing in Alternatives 1-3 is to be secured to the roof joists using $6 \mathrm{~mm}$ x $50 \mathrm{~mm}\left(1 / 4^{\prime \prime} \times 2^{\prime \prime}\right)$ self-tapping screws with the same spacing requirements as the plywood. The ceiling of the concrete masonry wall should comply with the roof sections previously mentioned. Hurricane straps were utilized in securing roof-to-wall connections and providing additional resistance to uplift loads. The Simpson Strong-Tie H15 straps can resist a maximum uplift of $5.8 \mathrm{kN}(1300 \mathrm{lbs})$, and were placed at each end of the roof joists and fastened to the studs with 12-10d nails (Simpson [8]). ASTM A307 anchor bolts were used to provide adequate wall-to-foundation anchorage. It was determined that $12 \mathrm{~mm}\left(1 / 2^{\prime \prime}\right)$ diameter bolts spaced at a maximum distance of $1.2 \mathrm{~m}$ (48 in) on center were sufficient to resist overturning and sliding of the structure.

\subsection{Retrofit door}

An integral component of the Retrofit Room design is a special door adequate enough to resist debris impact requirements. Existing doors were replaced with stronger steel doors that have been tested and conform to the Florida Building Code (FBC [2]) missile impact specifications. Standard 6-panel doors with 3hinge mount and dead bolt lock that are Miami-Dade County certified are sufficient for FBC debris impact resistance.

\subsection{Foundation}

In general, the Florida slab-on-grade foundation is $100 \mathrm{~mm}$ (4 in) thick with a continuous footing at the exterior edge, reinforced with steel wire mesh to prevent cracking and bending. It was determined that the $100 \mathrm{~mm}$ (4 in) concrete slab is adequate to support a wood-frame retrofitted shelter. However, installing a Retrofit Room with all CMU walls requires removing part of the existing 100 $\mathrm{mm}$ (4 in) slab and replacing it with a thickened one. This task is not only difficult and expensive but also impractical for homeowners with existing houses. For this reason, the maximum number of exterior load bearing CMU walls in a Retrofit room is restricted to two.

\subsection{Debris impact}

Potential damages from wind debris impact ranges from over pressurization of the building to injury or loss of life to occupants. Because of the danger 
associated with windborne debris, Florida structures located in hurricane-prone areas (regions with $190+\mathrm{km} / \mathrm{h}$ or $120+\mathrm{mph}$ basic wind speeds) are required to satisfy FBC debris impact criteria (FBC 2001). Results of missile impact testing conducted at Texas Tech University (TTU [3]) were used to extrapolate information and apply it to the Retrofit Room design herein. The TTU large missile impact testing criteria is a standard $50 \mathrm{~mm} \times 100 \mathrm{~mm}(2 \mathrm{in} \mathrm{m} 4$ in) wood stud weighing $6.8 \mathrm{~kg}(15 \mathrm{lbs})$ and traveling at $55 \mathrm{~km} / \mathrm{h}(34 \mathrm{mph})$, slightly heavier than the FBC specified missile. Table 2 lists the specimen materials and their corresponding missile impact performance. The TTU results provide evidence that the developed alternatives for the Retrofit Room designs pass FBC impact testing standard.

Table 2: $\quad$ Large missile impact test results.

\begin{tabular}{c|c}
\hline \hline Wall Cladding & $\begin{array}{c}\text { Threshold Missile Speed } \\
{[\mathrm{km} / \mathrm{h}(\mathrm{mph})]} \\
(1)\end{array}$ \\
\hline 1 layer 19 mm (3/4") plywood & $45(28)$ \\
\hline 2 layers 19 mm (3/4") plywood & $64(40)$ \\
\hline 3 layers 19 mm (3/4") plywood & $95(59)$ \\
\hline 1 layer 19 mm (3/4") plywood with 1 & $233(145)$ \\
layer of steel sheathing & \\
\hline \hline
\end{tabular}

\section{Cost analysis}

The cost analysis of retrofitting a typical interior room for existing Florida houses was based on the selected materials used herein. Actual prices for materials and labor were obtained from two Retrofit Rooms constructed in Tallahassee as demonstrations of the developed techniques. The wall retrofits utilized for these sample rooms were Alternatives 3 and 4 , comprised of one

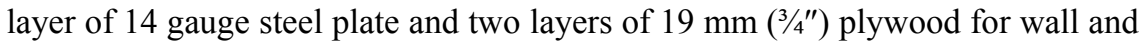
roof sheathing, respectively. The total cost including materials and labor were approximately $\$ 3,020\left(\$ 904 / \mathrm{m}^{2}\right.$ or $\$ 84 / \mathrm{sq}$. $\mathrm{ft}$.) and $\$ 3,150\left(\$ 1130 / \mathrm{m}^{2}\right.$ or $\left.\$ 105 / \mathrm{ft}^{2}\right)$ for the two rooms, respectively. These values are significantly lower than the published cost of FEMA Safe Room in an existing house with slab-on-grade foundation $(\$ 5400)$.

Cost analysis also showed that Alternatives 1 and 2 were the least cost effective as compared with Alternatives 3 and 4. For this reason, the Retrofit Room designs should be limited to the following three representative retrofit choices: (a) one layer of 14 gauge steel sheathing; (b) two layers of $19 \mathrm{~mm} \mathrm{(3/4^{ \prime \prime } )}$ plywood sheathing (Fig. 1); and (c) concrete masonry fully grouted with vertical bars spaced at $600 \mathrm{~mm}$ (24 in) on center. 


\section{Conclusions}

The following conclusions may be made based on the design and analysis of Retrofit Room techniques used herein for in-home shelter protection against hurricanes and tropical storms:

1. Typical existing interior rooms can be adequately reinforced with various combinations of materials used in construction to resist wind forces and windborne debris that act on wall and roof systems during extreme hurricanes or major tornadoes.

2. Retrofit Room designs developed in this study provide adequate protection from FBC specified hurricane wind speeds up to $225 \mathrm{~km} / \mathrm{h}$ (140 mph) and large debris impact. Such rooms can conveniently and safely shelter a family of four from wind damage.

3. The three representative and economic Retrofit Room designs developed consist of the following roof and wall reinforcing materials: (a) One layer of 14 gauge steel sheathing; (b) 2 layers of $19 \mathrm{~mm}\left(3 / 4^{\prime \prime}\right)$ plywood sheathing; and (c) fully grouted concrete masonry with vertical bars spaced at $0.6 \mathrm{~m}$ ( $24 \mathrm{in})$ on center.

4. The retrofit materials utilized in this study are of known performance and strength and easily available from local hardware stores.

5. The labor and material cost of installing a Retrofit Room is about $\$ 3,100$, well below the average cost to install a FEMA tornado Safe Room.

\section{Acknowledgement}

This study was performed under a research grant from the Florida Department of Community Affairs, Division of Emergency Management.

\section{References}

[1] Taking Shelter From the Storm: Building a Safe Room Inside Your House, Federal Emergency Management Agency FEMA-320/October 1998.

[2] Florida Building Code (FBC 2001), State of Florida.

[3] Texas Tech University, "Debris Impact Testing at Texas Tech University," Wind Science and Engineering Research Center, Texas Tech University, Lubbock Texas, February 2002.

[4] American Society of Civil Engineers, Minimum Design Loads for Buildings and Other Structures, ASCE 7-98, Reston, VA.

[5] Breyer, D.E., Design of Wood Structures, McGraw-Hill Inc., New York, 1993.

[6] Taly, N., Design of Reinforced Masonry Structures, McGraw-Hill Inc., New York, 2001.

[7] National Design Specification (NDS) for Wood Construction. ANSI / AF\&PA NDS-1997.

[8] "H Seismic and Hurricane Ties: Material Description and Installation," Simpson Strong-Tie Connectors 2001.

[9] National Hurricane Center, www.nhc.noaa.gov, last updated June 2002. 